\title{
An Analysis on Reading Strategies based on Metacognitive Awareness and Gender
}

\author{
Chandra Fauzi, Ashadi \\ Universitas Negeri Yogyakarta, Indonesia \\ E-mail: acengpolo94@gmail.com
}

\begin{abstract}
This article is based on survey research which sought to identify the reading strategies used by the first-semester graduate students and to reveal the most dominant strategies used by students of different gender. The participants of this study were first-semester graduate students $(\mathrm{N}=43)$ of a state teacher college. A five-point Likert Scale questionnaire named SORS (Survey of Reading Strategies) was deployed to collect the data concerning the use of reading strategies. The findings demonstrated that the first-semester students were greatly conversant in reading strategies with overall mean score of 3.82 which means a high level of awareness. The first-semester students consecutively preferred Problem Solving Strategies to Global Reading Strategies or Support Reading Strategies eventhough all of these three subscales fell into highly-used strategy. Female students were found to use the strategies more frequently that their male counterparts did. Also, the results of individual reading strategies use revealed that both genders tended to reread the text and to circle or underline information in the text to help them understand what they read. However, pedagogical implications on the use of metacognitive strategies that would help students activate their higher order thinking skills in reading needs to be given attention.
\end{abstract}

Keywords: reading strategies, metacognitive awareness, gender

\section{INTRODUCTION}

Reading is considered necessary for the overall improvement of students who are willing to enhance their language proficiency. Undeniably, reading is one of the best ways to expand one's horizon and acquiring new knowledge. As for EFL students, reading is an essential skill to master in order to ensure success not only in learning English but also in learning any context class where reading in English is required. Ahmed (2016, p. 189) emphasized that by enhancing reading skill, learners will make better improvement and progress in all other areas of learning.

Inevitably, one of the main prerequisites to succeed in foreign language learning is to be a proficient reader, which is necessary for EFL students. To become proficient reader, EFL students should use a variety of reading strategies. Utilizing reading strategies will facilitate EFL students in their effort to understand texts, to better comprehension and eventually to become proficient readers.

However, EFL students might not be aware of their reading strategies which impede their progress to be proficient readers. The awareness of reading strategies is beneficial for the improvement of EFL students' reading skills in English. As pointed out by Pressley and Afflerbach (1995) (in Mokhtari and Sheorey, 2002, p. 3) that "the main difference between skilled and unskilled readers is their awareness of the reading strategy use."

The awareness of reading strategies by Auerbah and Paxton (1997) and Carell et al, (1988) is known as metacognitive awareness or metacognitive control. This awareness is highly crucial to the 
improvement of EFL students reading skills. Moreover, students' reading ability is related to the awareness of reading strategies where low ability readers have a lower level of awareness of strategy use, and vice versa (Mokhtari and Sheorey, 2001, p. 16).

Another critical issue that has received little attention in reading strategy use is gender differences in using reading strategies among EFL students which is still relatively rare. A gap of knowledge still exists regarding the differences between male and female concerning their reading strategy use, especially at the university level. Moreover, questions still exist about whether or not males and females students significantly differ regarding the frequency and reading strategies they use (Poole, 2005, p. 8).

Therefore, exploring gender differences concerning reading strategy use is paramount important because it helps teachers or lecturers to find ways to maximize students' reading ability and hence their comprehension (Ahmad, 2015, p. 16). In this case, the information of gender differences in reading strategies can be valuable information for English lecturers.

Previous studies on reading strategy use have been focusing on researching ESL or EFL students either in lower or higher education (Sheorey and Mokhtari, 2001; Sari, 2011; Mamoudi, 2014; \& Dundar, 2016); however, little is known about EFL student teachers use of reading in Indonesian context. Therefore, this research which focused on EFL student teachers would provide valuable information regarding reading strategy use in different setting.

Considering the impact of reading strategy awareness and use which can enhance EFL students' reading ability and comprehension. This article seeks to examine whether the assumption that the first semester graduate students are not aware of their reading strategies is justified. The authors, then, focused the efforts to (1) scrutinize the use of reading strategies by the students, and (2) find out the most dominant reading strategies by students of different genders.

\section{Reading strategies}

Research has shown that readers usually apply various strategies and approaches to help them understand the written texts because reading comprehension requires readers to employ conscious and unconscious strategies to solve problems (Paris, Wasik, \& Turner, 1991). Therefore, using reading strategies is essential to achieve reading goals.

Different researchers have given various definitions of reading strategies. According to Block (1986, p. 465), "reading strategies indicate how readers identify the purpose for reading, what parts of the text they attend to, how they deal with making sense of the text, and how they overcome not understanding certain parts or words in text". Additionally, Cohen (1990) states that reading strategies are set of plans preferred and used by readers to reach reading goals.

On the other hand, Rajoo and Selvaraj (2010, p. 1301) define reading strategies as "how readers interact with the written texts and how these strategies help to enhance text comprehension which includes mental plans."

Based on the definition above it can be concluded that reading strategies are mental plans or procedures (e.g., setting purposes for reading) which readers use deliberately when interacting with texts in order to help them comprehend texts and to help them overcome difficulties in reading.

\section{Types of reading strategies}

As important as using reading strategies in enhancing reading comprehension, recognizing types of reading strategies in reading is also important to have more options when one reading strategy does not achieve the result the 
learners want in overcoming difficulties in comprehending the text.

Mokhtari and Reichard (2002, p. 252) classify Reading Strategies in three broad categories as "Global Reading Strategies (GLOB), Problem Solving Strategies (PROB) and Support Strategies (SUP)" as the theoretical foundation of SORS questionnaire which the authors used in this research.

Global Reading Strategies refer to those intentional, carefully planned techniques by which learners monitor or manage their reading such as using prior knowledge, matching reading purposes to the content of reading by previewing the text, utilizing context clues and text structure, and skimming through the text.

Meanwhile, Problem Solving Strategies are the activities and processes performed by the readers while they are dealing with the text directly. Readers use these strategies as confined, attentive techniques when they have problems in comprehending texts. Some examples of problem reading strategies are reading slowly and carefully, adjusting reading speed or rate, rereading the text, visualizing the information in the text, and guessing the meaning of unknown words.

Support Strategies are the use of essential assistance system aimed to support the reader in understanding text. These include taking notes when reading, paraphrasing and summarising information in the text, using reference materials (e.g., using a dictionary), summarising, and discussing reading with others.

\section{Metacognition}

Since its development, metacognition has received considerable attention in research on language learning especially, in reading because metacognition highlights how learner makes plans for reading, monitor the reading process and evaluate how one has learned (Jacob and Paris, 1987). This notion is supported by Mokh- tari and Reichard (2002, p. 249) who state that "awareness and monitoring one's comprehension processes' which are often referred in the literature as metacognition are critically important aspects of skilled reading."

The term 'metacognition' was first coined by American Developmental psychologist Flavell $(1979$, p. 2) in the area of cognitive psychology. According to Flavell, metacognition refers to one's knowledge and cognition about cognitive phenomena. Similarly, Anderson (2002, p. 1) defines metacognition as 'thinking about thinking,' and it reflects one's ability to understand what is known. Gassner (2009, p.7) provides a more detailed explanation where he explains that metacognition is the understanding one own knowledge that he or she could describe or express verbally. In other words, metacognition is about being aware of one's own mind when solving problems in reading a text which implies that one has to purposively and continously adapt and choose appropriate strategy in solving reading problems to understand what is being read.

Based on the explanation above, metacognition can be defined as the awareness and understanding of our thinking processes. Metacognition allows the students to plan, to monitor, and to assess their understanding and performance related to their activities they are doing.

\section{Metacognitive awareness in reading}

Mohktari and Reichard (2002, p. 249) believe that metacognitive awareness is crucial in reading comprehension because it differentiates between skilled and unskilled readers. Paris and Jacobs (1984) argues that good readers actively plan their reading, adapt reading strategies, regurarly evaluate his reading by thinking about reading topic, continously making connection among ideas in the passage then finally checking out his understanding. Contradictively, poor 
readers are absent from those acts of good readers.

Mokhtari and Sheorey (2001, p. 2) define metacognitive awareness as readers' cognitive ability of self-control by using reading strategies in the reading process the learners use to monitor and enhance comprehension.

On the other hand, Noshad (2008, p. 17) gives a slightly different but more complete explanation where he argues that metacognitive awareness is about individual awareness of his progress in learning process or the process of problem solving. This awareness also relates to what should be done, what has been achieved and what to do in learning contexts or problemsolving situation.

Based on the statements above, the authors concludes metacognitive awareness can be defined as the learners' awareness of how they read and use strategies in reading to make them mindful of what they are reading. In other words of why they are reading (finding purpose), and of how the strategies they are using might be used differently in a different situation to accomplish reading task. Shortly, metacognitive awareness helps learners to be active and more conscious readers, so they will find the most effective reading strategies to enhance reading comprehension.

\section{Gender differences in reading strategy use}

In this part, the authors present several studies on gender differences in reading strategies; specifically, in the context of metacognitive reading strategies.

A study on gender differences in metacognitive strategy use was conducted by Sheorey and Mokhtari (2001, p. 15) on 152 ESL students and 150 native-Englishspeaking American students. They concluded that, female students in general reported using specific strategies more frequently than did their male counterparts. In the case of ESL students, their findings showed that females use language learn- ing strategies (not specifically reading strategies) more frequently than males.

Ahmad (2015: 22) confirmed that there was a significant difference between males and females in which females used more strategies and scored higher than males in all categories of reading strategies. Similarly, Chen and Chen (2015) also found that female students $(\mathrm{M}=3.83)$ had a higher overall mean than male students $(M=3.68)$, and both genders reported using reading strategies with high frequency in which the difference between male and female students was significant $(\mathrm{t}=-5.15 ; \mathrm{p}<.001)$. The results above showed that female students always outperformed male students in reading strategy awareness which implied that female students might have better ability in reading than male students.

Based on the findings above, gender differences in reading strategy use; specifically, metacognitive reading strategies have become a keen interest in research both in the context of EFL and ESL learners. Also, these findings strongly suggest that gender differences in reading strategies are essential to investigate for gaining more conclusive findings.

\section{METHODS \\ Design of the research}

This study was a quantitative
survey design which employs a questionnaire to gather information and data from a group of individuals (Ary et al., 2010, p. 28). It is a one-shot survey aimed at describing the characteristics of a group in one point in time (Mertens, 2010, p. 177). Based on the scope, this study is categorized as a census of intangibles where the focus is to analyze the reading strategies of entire first-semester graduate students of a state teacher college in the academic year of 2018/2019.

\section{Setting and participants}

The authors conducted a census or complete enumeration to the population in 
order to collect information regarding every member of the targeted population. According to Ary et al., (2010, p. 373) census is a survey that covers or includes each member of a population as the participants of the study. Thus, the participants of this study were 43 first-semester graduate students of two classes (A and B) of a State Teacher College in the academic year of 2018/2019 in which the number female students $(\mathrm{N}=39)$ and male students $(\mathrm{N}=14)$.

\section{Data collection}

The authors adopted Survey of Reading Strategy (SORS) developed by Mokhtari and Sheorey (2002, pp. 1-10). SORS is primarily designed to measure the types and frequency of reading strategies of ESL/EFL students (Mokhtari and Sheorey, 2002, p. 4).

Precisely, 30 items of 5 Likertscale were in the questionnaire which dig the use reading strategies use in understanding academic materials (such as journal articles, textbooks, class notes). The questions are classified into three types, namely Global Reading Strategies (13 items), Problem Reading Strategies (8 items), and Support Reading Strategies (9 items) (see Appendix I).

\section{Data analysis}

To answer the research questions, the authors conducted a descriptive statistics analysis. Specifically, the descriptive statistic such as frequency distribution and the measure of central tendency (mode, median and mean) were taken into consideration to answer research questions number one and two.

Further, the authors analysed the data in three steps. First, we calculated the frequency of students' responses and the mean score of each reading strategies and subscales (GLOB, PROB, and PROB). Then, we identified the types of reading strategies used the respondents based on the mean score of each reading strategy subscale to answer the first research question. Finally, to find out the most dominant reading strategies of male and female students, we calculated the mean score of overall responses of both genders on each item and each strategy subscale. Then, we categorized the level of reading strategies use by both genders based on the classification table below:

Table 1. The range of mean scores of SORS

\begin{tabular}{lll}
\hline \multicolumn{1}{c}{ Qualification } & \multicolumn{1}{c}{ Description } & Mean \\
\hline \multirow{2}{*}{ High } & Always or almost always used & 4.5 to 5.0 \\
\multirow{3}{*}{ Moderate } & Usually used & 3.5 to 4.4 \\
\multirow{2}{*}{ Low } & Sometimes used & 2.5 to 3.4 \\
& Only occasionally & 1.5 to 2.4 \\
& Never or Almost Never & 1.0 to 1.4 \\
\hline \multicolumn{3}{c}{ Adopted from Oxford and Burry Stock (1995) }
\end{tabular}

\section{Procedures}

The authors developed a questionnaire and chose target samples to collect data in this study. We decided to adopt the SORS questionnaire to measure the use of reading strategies because it is the most valid tool to measure reading strategies of ESL and EFL learner (Mokhtari and Sheorey, 2002, p. 4). Thus, the we did not need to pilot test the questionnaire.

Before administering the questionnaire, the authors conducted an informal interview with five freshman students to gain infomation concerning their use of reading strategies which resulted in an assumption that the students might not be aware of these. The authors 
distributed the questionnaire to two classes (Class A and B) in two different days. In each class, we provided a brief explanation on the how to fill the questionnaire as well as how the students would score their questionnaire to provide them the level of awareness of their reading strategies (see Appendix III). We also reminded the respondents that no right or wrong answers.

Therefore they had to provide answers most appropriate to them.

More importantly, the authors reminded the respondents that the reading strategies assessed through the SORS questionnaire were the reading strategies they used when reading academic materials such as research articles, textbook, and campus-related materials, not newspaper or magazine. Further, the authors analyzed the data of students' reading strategies by calculating the frequency and mean score of the responses with the aid of computer software (Microsoft Excel 2013). Then, the authors classified mean scores based on the mean range of SORS questionnaire. Finally, the authors described the data supported by related theories and findings from previous studies.

\section{FINDINGS}

In this part, the authors presented the findings subsequently from the de- scriptions of the overall use of reading strategies and each category of reading strategies to provide answers to research question number one. Concerning research question two, the authors illuminated the most dominant reading strategies used by each male and female students in each category of reading strategies and five most dominant individual strategies of the reading strategies. Additionally, the authors also utilized tables and figures to depict the findings of the use of reading strategies by both genders.

\section{The description of the overall use of reading strategies}

The authors calculated the mean of the responses to investigate the overall score of reading strategies used by the first semester students while reading academic materials. Three levels of strategy usage suggested by Oxford and BurryStock (1995) are high level (mean score $\geq$ 3.5 ); moderate level (mean score $\geq 2.5$ but $\leq 3.4$ ); and low level (mean score $\leq 2.4$ ). These levels were used to classify the participants' SORS results. Table 2 shows the mean scores of first semester students' on overall and each subscale (Global Reading Strategies, Problem Solving Strategies, Support Reading Strategies).

Table 2. Participants' mean scores of SORS

\begin{tabular}{lcl}
\hline \multicolumn{1}{c}{ Reading Strategies } & Mean Score & Level \\
\hline Global & 3.83 & High \\
Problem Solving & 4.04 & High \\
Support & 3.62 & High \\
\hline \multicolumn{1}{c}{ TOTAL } & 3.83 & High \\
\hline
\end{tabular}

The overall mean score of students' reading strategies was 3.83 which stands at a high level of strategy usage. Concerning the three sub-strategies, Problem Solving Reading Strategy ranked at the first place $(M=4.04)$ which belong to the highfrequency level followed by Global Reading Strategies $(M=3.83)$ and Support
Reading Strategies $(\mathrm{M}=3.62)$ which both were at the high level of strategy use.

The overall mean score and the mean scores of each sub-strategy demonstrated that the students employed reading strategies frequently in English Reading, specifically in English academic materials. This high-frequency level of reading strat-

6 - An Analysis on Reading Strategies based on Metacognitive.... 
egy use also indicated that the students were highly aware of their usage of reading strategies as high strategy users.

\section{The description of each category of reading strategies}

a. Problem solving strategies

Among the three sub-strategies, the use of Problem Solving Reading Strategies ranked at the first place $(M=4.04)$ which refer to activities and processes performed by the readers when dealing with the text directly and facing problems in comprehending texts. For instance, adapting to reading speed when the textual information becomes easy or difficult to understand, predicting the meaning of unknown vocabulary, and rereading the text to understand the text better.
As displayed in table 3 below, all items were at the high frequency used reading strategies. The most frequently used strategy was PROB 25: "When text becomes difficult, I re-read it to increase my understanding" ( $\mathrm{M}=4.60)$ and followed by PROB 9: "I try to get back on track when I lose concentration" $(\mathrm{M}=4.25)$ and PROB 14: "When text becomes difficult, I pay close attention to what I am reading” $(\mathrm{M}=4.10)$.

The above three Problem Solving Strategies indicated that when the students read academic materials, they would reread the text to enhance their understanding, try to pay attention when losing concentration, and give closer attention to what they are reading.

Table 3. The use of problem solving reading strategies

\begin{tabular}{clccc}
\hline No. & \multicolumn{1}{c}{ Items of PROB } & Total Score Per Item & Mean & Level \\
\hline 1 & $\begin{array}{l}\text { 7. I read slowly and carefully to make sure } \\
\text { I understand what I am reading. }\end{array}$ & 157 & 3.93 & High \\
\hline 2 & $\begin{array}{l}\text { 9. I try to get back on track when I lose } \\
\text { concentration. }\end{array}$ & 170 & 4.25 & High \\
\hline 3 & $\begin{array}{l}\text { 11. I adjust my reading speed according to } \\
\text { what I am reading. }\end{array}$ & 157 & 3.93 & High \\
\hline 4 & $\begin{array}{l}\text { 14. When text becomes difficult, I pay } \\
\text { close attention to what I am reading. }\end{array}$ & 164 & 4.10 & High \\
\hline 5 & $\begin{array}{l}\text { 16. I stop from time to time to think about } \\
\text { what I am reading. }\end{array}$ & 140 & 3.50 & High \\
\hline 6 & $\begin{array}{l}\text { 19. I try to picture or visualize information } \\
\text { to help me remember what I read. }\end{array}$ & 157 & High \\
\hline 7 & $\begin{array}{l}\text { 25. When text becomes difficult, I re-read } \\
\text { it to increase my understanding. }\end{array}$ & 184 & High \\
\hline 8 & $\begin{array}{l}\text { 28. When I read, I guess what the meaning } \\
\text { of unknown words or phrases. }\end{array}$ & 163 & High \\
\hline
\end{tabular}

b. Global reading strategies

The second frequently used substrategy by the first semester students was Global Reading Strategies $(\mathrm{M}=3.83)$. Global Reading Strategies are those carefully planned techniques used by learners to monitor or manage their reading. For instance, setting the purposes for reading, using background knowledge to understand texts, and using context clues to guess the meaning of words. The following table 4 illustrates the findings. 
Table 4. The use of global reading strategies

\begin{tabular}{|c|c|c|c|c|}
\hline No. & Items of GLOB & Total Score Per Item & Mean & Level \\
\hline 1 & 1. I have a purpose in mind when I read. & 158 & 3.95 & High \\
\hline 2 & $\begin{array}{l}\text { 3. I think about what I know to help me un- } \\
\text { derstand what I read. }\end{array}$ & 164 & 4.10 & High \\
\hline 3 & $\begin{array}{l}\text { 4. I take an overall view of the text to see } \\
\text { what it is about before reading it. }\end{array}$ & 156 & 3.90 & High \\
\hline 4 & $\begin{array}{l}\text { 6. I think about whether the content of the text } \\
\text { fits my reading purpose. }\end{array}$ & 158 & 3.95 & High \\
\hline 5 & $\begin{array}{l}\text { 8. I review the text first by noting its charac- } \\
\text { teristics like length and organization. }\end{array}$ & 130 & 3.25 & Medium \\
\hline 6 & $\begin{array}{l}\text { 12. When reading, I decide what to read } \\
\text { closely and what to ignore. }\end{array}$ & 150 & 3.75 & High \\
\hline 7 & $\begin{array}{l}\text { 15. I use tables, figures, and pictures in the } \\
\text { text to increase my understanding. }\end{array}$ & 172 & 4.41 & High \\
\hline 8 & $\begin{array}{l}\text { 17. I use context clues to help me better un- } \\
\text { derstand what I am reading. }\end{array}$ & 157 & 3.93 & High \\
\hline 9 & $\begin{array}{l}\text { 20. I use typographical features like boldface } \\
\text { and italics to identify key information. }\end{array}$ & 151 & 3.78 & High \\
\hline 10 & $\begin{array}{l}\text { 21. I critically analyze and evaluate the infor- } \\
\text { mation presented in the text. }\end{array}$ & 134 & 3.35 & Medium \\
\hline 11 & $\begin{array}{l}\text { 23. I check my understanding when I come } \\
\text { across new information. }\end{array}$ & 158 & 3.95 & High \\
\hline 12 & $\begin{array}{l}\text { 24. I try to guess what the content of the text } \\
\text { is about when I read. }\end{array}$ & 157 & 3.93 & High \\
\hline 13 & $\begin{array}{l}27 . \text { I check to see if my guesses about the text } \\
\text { are right or wrong. }\end{array}$ & 143 & 3.58 & High \\
\hline
\end{tabular}

For Global Reading Strategies, 6 out of 13 items were reported as being a high frequently used strategy (mean $\geq 3.5$ ). The most frequently used strategy was GLOB 14: "I use tables, figures, and pictures in the text to increase my understanding" $(\mathrm{M}=3.79)$ which indicated that when reading academic materials the students not only tried to understand the text but also use tables, figures, and pictures to understand better what they read.

The second most frequently used strategy was GLOB $3(\mathrm{M}=4.10)$ "I think about what I know to help me understand what I read" and the third frequently used
Global Reading Strategies was GLOB 23: "I check my understanding when I come across new information." This result indicates that the first-semester students made use of their prior knowledge to help them understand new information.

c. Support reading strategies

The third frequently used reading strategy was Support Reading Strategies $(M=3.62)$. Support Reading Strategies are employed by learners to enhance their understanding via different aids or approaches. 
Table 5. The use of support reading strategies

\begin{tabular}{lllll}
\hline No & \multicolumn{1}{c}{ Items of SUP } & Total Score Per Item & Mean & Level \\
\hline 1 & $\begin{array}{l}\text { 2. I take notes while reading to help me un- } \\
\text { derstand what I read }\end{array}$ & 130 & 3.25 & Medium \\
\hline 2 & $\begin{array}{l}\text { 5. When text becomes difficult, I read aloud } \\
\text { to help me understand what I read }\end{array}$ & 147 & 3.68 & High \\
\hline 3 & $\begin{array}{l}\text { 10. I underline or circle information in the } \\
\text { text to help me remember what I read. }\end{array}$ & 172 & High \\
\hline $4 \quad \begin{array}{l}\text { 13. I use reference materials (e.g., diction- } \\
\text { ary) to help me understand what I read }\end{array}$ & 157 & 3.93 & High \\
\hline $\begin{array}{l}\text { 18. I paraphrase (restate my ideas in my } \\
\text { own words) to better understand what I } \\
\text { read. }\end{array}$ & 142 & 3.55 & High \\
\hline 6 & $\begin{array}{l}\text { 22. I go back and forth in the text to find } \\
\text { relationships among ideas in it. }\end{array}$ & 152 & 3.80 & High \\
\hline 7 & $\begin{array}{l}\text { 26. I ask myself questions I like to have an- } \\
\text { swered in the text }\end{array}$ & 132 & 3.30 & Medium \\
\hline 8 & $\begin{array}{l}\text { 29. When reading, I translate from English } \\
\text { into my native language }\end{array}$ & 124 & 3.10 & Medium \\
\hline $\begin{array}{l}\text { 30. When reading, I think about information } \\
\text { in both English and my mother tongue. }\end{array}$ & 144 & 3.60 & High \\
\hline
\end{tabular}

As shown in table 5 above, 5 out of 9 items were reported as being high frequently used (mean $\geq 3.5$ ). The most frequently used strategy was SUP 10 $(\mathrm{M}=3.82)$ : "I underline or circle information in the text to help me remember it" followed by SUP 13 (3.93): "I use reference materials (e.g., using dictionary) to help me understand what I read" and SUP 22 (M=3.80): "I go back and forth in the text to find relationships among ideas in it".

The results above indicated that the first freshmen year students had a habit of circling or underlining information they considered necessary in the text. Also, they utilized a dictionary to assist them when finding new words during their reading time. Since graduate students should be able to think critically, they tended to go back and forth in reading to spot relationships among ideas.

d. The result of the most dominant reading strategies used by each male and female students

Regarding the second research question which seeks for the information on most dominant reading strategies used by each male and female students, the finding is listed in the following table:

Table 6. Reading strategy use by female and male students

\begin{tabular}{lccc}
\hline \multirow{2}{*}{ Reading Strategies } & \multicolumn{2}{c}{ Mean Scores } & \\
& Female & Male & Level \\
\hline Global & 3.75 & 3.79 & High \\
Problem Solving & 4.04 & 4.00 & High \\
Support & 3.62 & 3.56 & High \\
\hline \multicolumn{1}{c}{ Total } & 3.80 & 3.78 & High \\
\hline
\end{tabular}


Concerning the most dominant reading strategies among the three reading strategy subscales, female students' most dominant reading strategy was Problem Solving Reading Strategies ( $M=4.04)$ which was at high frequently used reading strategies. Almost similar to their female conterparts, male students were also tended to employ Problem Solving Reading Strategies $(M=4.00)$ although slightly lower than the former.

The second most dominant reading strategy used by female students was Global Reading Strategies which was at as a high frequency used strategy $(\mathrm{M}=3.75)$. Similarly, the second most favored reading strategy of male students was Global Reading Strategy which was slightly higher than female students mean score $(M=3.79)$. Furthermore, Support reading strategy was the least used by female and male students in which the mean score of female respondents $(M=3.62)$ which was slightly higher than male students $(\mathrm{M}=3.56)$.

Regardless of the differences above, none of the three sub-strategies above were reported as being a low used strategy. The high level of reading strategies application indicates that both genders utilized all reading strategies to enhance their reading comprehension. Furthermore, the overall mean score of the three reading strategy subscales showed that female students $(\mathrm{M}=3.80)$ had higher mean score than male students $(M=3.78)$.

The authors also presented the use of reading strategy by each male and female student in form of graph to below:

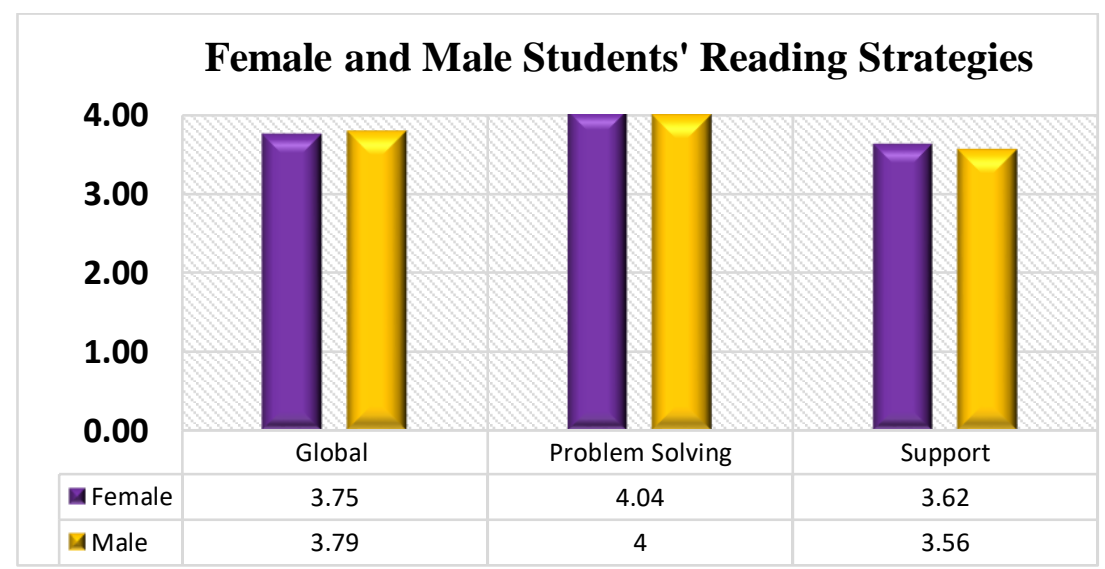

Figure 1. The Result of Reading Strategies on Each Strategy Subscale

Furthermore, in order to gain more insights regarding the most dominant individual reading strategies used by each male and female students, the authors presented the five most dominant individual strategies used by both genders the following figure. 


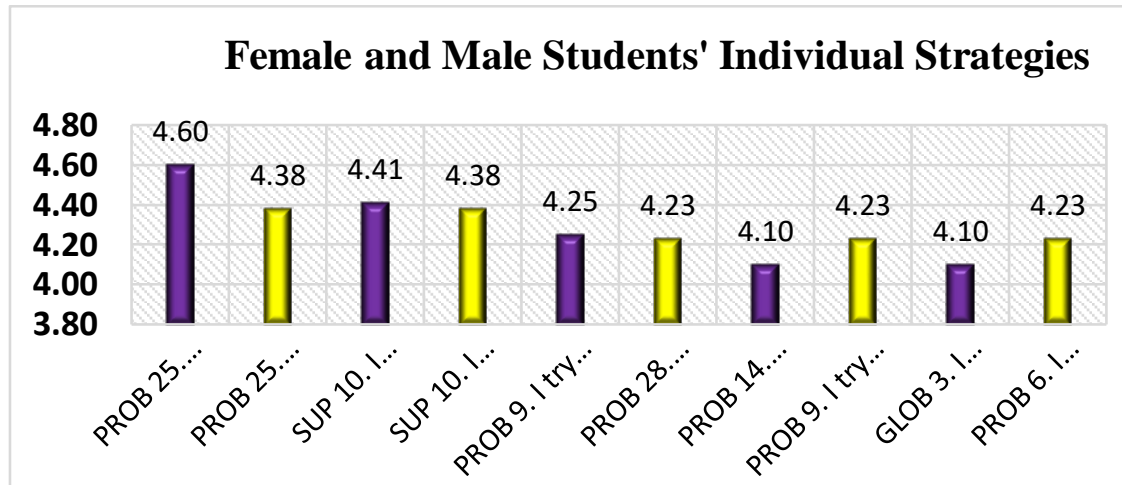

Figure 2. Five Most Dominant Individual Reading Strategies Used by Female Students

The results above demonstrate that in reading academic materials, both male and female students tended to read the text back to understand better what they read. Also, they would always underline essential points on the text so that later when they need to re-read the text, the keywords would speed up their reading and help them to find the gist of what they read. Further, both male and female students activated their prior knowledge to assist them in understanding new words or information. The results of above also indicated that regarding individual strategies, Problem Solving reading strategies dominated the strategies that the students utilized during their reading.

\section{DISCUSSION}

Based on the finding, the use of reading strategies by first-semester graduate students covers the complete classification of three sub-strategies of SORS (Survey of Reading Strategies) by Mokhtari and Sheorey (2002). Nevertheless, the average score of each sub-strategy and individual strategy slightly varied from one to another. Regardless, based on the overall average reading strategies, the authors classified the first-semester graduate students' reading strategy use as high use. This high use of reading strategy implied that the students were highly aware of the reading strategies and utilized various reading techniques frequently in helping them understand what they read.
In addition, the sequence pattern of reading strategies subscales by the students fell into Problem Solving Strategies followed by Global Reading Strategies, and Support Reading Strategies which were similar to previous studies (Poole, 2005; Li, 2010; Aziz, et al., 2011; Riazi \& Alhaqbani, 2012; Magogwe, 2013; Ahmad, 2015; and Alami, 2016) which employed SORS questionnaire to investigate the use of reading strategies in different contexts. However, there was no clear explanation of why the similarities of preference occurred among EFL and EFL students.

Regarding the most dominant reading strategies used by each male and female students, the students employ each reading strategy subscale at frequent high use with Problem Solving Reading Strategies as the most frequently used strategy. As previously explained, readers employed Problem Solving Strategies when they are directly dealing with the text to counter difficulties in reading. Since the respondents were graduate students who are demanded to read extensively in college, it is evident that they would frequently employ techniques such as rereading the text, adjusting the reading speed, and guessing the meaning of unknown words would when encountering various problems when reading in.

Moreover, this result was in line with the previous researchers who also consistently found out that college 
students tended to use Problem Solving Strategies in reading academic materials (Mokhtari and Reichard, 2002; Tabatabaie \& Assar, 2011; Temur \& Bahar, 2011; Yuksel \& Yuksel, 2012; Shikano, 2013; and Dundar, 2016). Further, the two other strategies favored by both genders at high frequently used strategy were similar in which Global Reading Strategies as the second most preferred and Support Reading Strategies as the third most frequently used.

In Global reading strategies both genders frequency use was almost identical, but for Support Reading Strategies female used them more often than their counterparts which implied that female students employed strategies such as taking notes while reading, paraphrasing, using a dictionary and picturing the information in both English and mother tongue more often than male students.

Although both genders used all reading strategy subscales at the highfrequency level, the small difference of the overall mean score between male and female students suggested that female students them more frequently than their male counterparts. Previous studies on gender differences in reading strategies have frequently found out the female students were more aware of reading strategies than male students. The superiority of female students implied they are highly likely to perform better in reading than male students because of their high awareness of reading strategies (Poole, 2005; Poole, 2010; Al-Daiwaideh \& Al-Saadi, 2013; Madhumati \& Ghosh, 2012; Kudeir et al., 2012; and Chen \& Chen, 2015).

In terms of individual strategies use, out of 30 items, only five strategies fell into moderate use strategies while 25 strategies were at high-level reading strategies use. Those moderately use strategies such as taking note while reading, reviewing text organization, critically analyzing and evaluating information, posing questions while reading, and translating the information from English into native language should be improved to enhance understanding while reading. The lecturers could teach the students on how to take note effectively, to critically analyze the information presented in the text, and to actively question the information during teaching and learning process. By enabling the students to employ all strategies at frequent high use, the possibilities to become proficient readers are feasible. Thus, training the students on how to use the strategies should be taken into consideration to develop students' reading skills.

To understand the use of reading strategies by each male and female students, the authors further examined the five most used strategies by the students. The authors found out that both genders would read the text more than once to increase their understanding. They also would highlight essential information in text and guess the meaning of unfamiliar words when reading academic materials. Moreover, they would try to concentrate fully on their reading to ensure that they would not lose track of their reading. The determination of keeping on the track when reading indicates that the respondents had a strong willingness to maintain their focus during reading and the reason for using these strategies might because the students considered it as the most basic strategies which may not require high awareness of reading strategy use (Kocaman and Berkadesler, 2016, p. 266).

\section{CONCLUSIONS}

Based on the discussion, the authors can draw several conclusions. First, students used each strategy subscale of reading strategies (Global, Problem Solving, and Support) at high-frequency use with Problem Solving strategies as the 
most frequently used strategy, followed by Global Reading strategies and Support Reading Strategies. The preference was in line with the previous studies which suggest that university students who have high reading proficiency tend to use Problem Solving Strategies. Such preference of Problem Solving Strategies occured when dealing with texts directly, the students would utilize various techniques to maintain their concentration to understand the texts. Therefore, the author concluded that the first-semester graduate students were highly aware of reading strategies which also implied that they had high proficiency in reading.

Gender-wise, the overall usage of all reading strategies firmly showed that female students utilized reading strategies more frequently than did male colleagues. It can mean that female students had a greater awareness of reading strategies than the male students with an implication that the female students were likely to perform better in reading that male student. This result is in line with Oxford (1993) who asserts that ESL female students utilize learning strategies more frequently thantheir male counterparts leading to a higher reading proficiency.

In terms individual use of reading strategies, both groups tended to re-read the text when they faced difficulties in reading and made use of circling or underlining keywords to retain the information. Such efforts are unserstandable as these participants wish to speed up their reading comprehension information retention for further oral or written reproduction.

This study has demonstrated the most frequently used strategy and the different preference between the two gender groups. Pedagogically, this study provides a new insight that students do make efforts to understand academic texts although the have not critically analysed and evaluated their readings as reflcted in the data. Further instructional efforts need to be directed towards improving the aware- ness to read by involving their higher order thinking skills or activating their metacognition.

\section{REFERENCES}

Abu-Snoubar, T. K. (2017). The Metacognitive Reading Strategies Employed by Jordanian English as a Foreign Language Students at AlBalqa Applied University. Journal of Literature, Languages and Linguistics, 35, 16-27.

Ahmad, M.S. (2015). Metacognitive Awareness of Reading Strategies among French Language Students: Is There a Different between Genders? International Journal of Arts \& Sciences, 8(2), 13-28.

Ahmed, S. (2016). Reading Habit and Attitudes of UMSKAL Undergraduate. International Journal of Applied Linguistics \& English Literature, 5(2), 189-201.

Alami, M. (2016). Cross-Gender Comparison of Metacognitive Strategies Utilized by Omani Students in Reading Comprehension Classes. International Journal of Applied Linguistics and English Literature, 5(4), 20-28.

Al-Dawaideh, A.M., \& Al-Saadi, I.A. (2013). Assessing Metacognitive Awareness of Reading Strategy Use for Students from the Faculty of Education at the University of King Abdulaziz. Mevlana International Journal of Education, 3(4), 223-235.

Alhaqbani, A., \& Riazi, M. (2012). Metacognitive awareness of reading strategy use in Arabic as a second language. Reading in a Foreign Language, 24(2), 231255.

Alkhawaldeh, A. (2012). The reading comprehension strategies employed by second secondary students in Jordan. A paper 
submitted and presented at a conference in University of Riverside, California, USA.

Anderson, N. J. (2002). The role of metacognitive in second language teaching and learning. Center For Applied Linguistic-Eric Clearinghouse on Languages and Linguistics. Retrieved from https://www.gpo.gov/fdsys/p $\mathrm{kg} /$ ERIC-ED463659/pdf/ERICED463659.pdf.

Arrastia, M.C., Zayed, A.M., \& Elnagar, H.Z. (2016). Metacognitive of Reading Strategies among English as a Foreign Language (EFL) Preservice Teachers: An Exploration of Gender and Developmental Differences. International Research in Higher Education, 1(2), 46-57.

Ary, D., Jacobs, L.C., Sorensen, C., \& Razavieh, A. (2010). Introduction to Research in Education. (8th ed.). United States of America: Wardsworth Publishing.

Auerbach, E., \& Paxton, D. (1997). It is not the English Thing: Bringing reading research into the ESL classroom. TESOL Quarterly, 31, 237-261.

Aziz, N.A., Ab Rahim, S., Harun, E. H. B., Adzmi, N. A., Ahmat, H., Bidin, S., Shaharudin, M. R. (2011). The Reading Strategies Awareness among English as A Second Language (ESL) Learners in Malaysia's University. Theory and Practice in Language Studies, 1(7), 778-784.

Block, E. (1986). The comprehension strategies of second language readers. TESOL-Quarterly, 20, 163494.

Chen, K. T., and Chen, S. C. (2015). The Use of EFL Reading Strategies among High School Students in Taiwan. The Reading Matrix: An International Online Journal, 15(2), 156-166.
Cohen, A. (1990). Language learning: Insights for learners, teachers, and researchers. Boston: Heinle \& Heinle Publishers.

Dundar, S. (2016). Determining EFL students' awareness of metacognitive reading strategies. ELT Research Journal, 5(1), 47-49.

Flavell, J. H. (1979). Metacognition and cognitive monitoring: A new area of

cognitive-developmental inquiry. California: Stanford University.

Gassner, L. (2009). Developing metacognitive awareness - a modified model of a PBL-tutorial. A thesis of Bachelor Degree at Malmo University: Published.

Hoang, N. (2016). The Relationship Between Reading Strategy Use and Reading Proficiency of Vietnamese Students in the UK. M.A Thesis. Northumbria University, Published by British Council ELT Master's Dissertation Awards.

Hoang, N. M. (2016). The Relationship between reading Strategy Use and Reading Proficiency of Vietnamese Students in the UK. British Council: University of North Umbria. British Council ELT Master's Dissertation Awards: Commendation.

Jacobs, L.L. \& Paris, S.G. (1987). Children's metacognition about reading: Issues in definition, measurement, and instruction. Educational Psychologist, 22, 255278.

Jafari, S.M., \& Shokrpour, N. (2012). The Reading Strategies Used by Iranian ESP Students to Comprehend Authentic Expository Texts in English. International Journal of Applied Linguistics \& English Literature, 1(4), 102-113.

Kocaman, O., \& Beskardesler, S. (2016). Metacognitive Awareness of Reading Strategy Use by English Language Teaching Students in Turk- 
ish Context. Sakarya University Journal of Education, 6(2), 254269.

Kudeir, R., Mableh, N., Nsser, H., \& Alkawaldeh, M. (2012). The degree to which Undergraduate Yarmouk University Students have practiced strategic reading as related to some variables. Islamic University Journal of Education and Psychological Studies, 20(2), 671-704.

Li, F. (2010). A study of English Reading Strategies Used by Senior Middle School Students. Asian Social Science, 6(10), 184-192.

Madhumathi, P., and Ghosh, A. (2012). Awareness of reading strategy use of Indian ESL students and the relationship with reading comprehension achievement. Canadian Center of Science and Education, 5(12), 131-140.

Magogwe, J. (2013). Metacognitive awareness of reading strategies University of Bostwana English as second language students of different academic reading proficiences. Reading \& Writing, 4(1), 1-8.

Mahasneh, A., Alkawaldeh M., Almakanin, H. (2016). Assessing Students' Metacognitive Awareness Reading Strategies in Jordan. North American Journal of Psychology, 18(2), 229-238.

Mahmoudi, E. (2014). Reading Strategy Use among Iranian EFL Learners. International Journal of Language Learning and Applied Linguistics World, 6(1), 371-378.

Mertens, D.M. (2010). Research and Evaluation in Education and Psychology: Integrating Diversity with Quantitative, Qualitative, and Mixed Methods. New York: Sage Publications.

Mokhtari, K. \& Reichard, C. A. (2002). Assessing students' metacognitive awareness of reading strategies.
Journal of Educational Psychology, 94(2), 249-259.

Mokhtari, K., \& Sheorey, R. (2002). Measuring ESL students' awareness of reading strategies. Journal of Developmental Education, 25(3), 2-10.

Noshad, P.P. (2008). Cognition about cognitions: the theory of metacognition. Retrieved from https://files.eric.ed.gov/fullte xt/ED502151.pdf.

Oxford, R. L. (1993). Instructional implications of gender differences in second/foreign language (L2) learning styles and strategies. Applied Language Learning, 4(1\&2), 65-94).

Oxford, R., \& Burry-Stock, J. (1995). Assessing the use of language learning strategies worldwide with the ESL/EFL version of the strategy inventory for language learning SILL. System, 23, 1-23.

Paris, S. G., \& Jacobs, J. E. (1984). The benefits of informed instruction for Children's reading awareness and comprehension skills. Child Development, 55, 2083-2093.

Paris, S. G., Wasik, B. A., \& Turner, J. C. (1991). The development of strategic readers (In R. Barr, M. L. Kamil, P. Mosenthal, \& P. D. Pearson (Eds.). Handbook of reading research, 2:609-640). Mahwah, NJ: Erlbaum.

Poole, A. (2005). Gender differences in Reading Strategy Use among ESL College students. Journal of College Reading and Learning, 36(1), 7-20.

Poole, A. (2010). The reading strategies used by male and female English language learners: A study of Colombian high school students. The NERA Journal, 46(1), 55-63.

Sari, A.A. (2011). An Investigation of Metacognitive Reading Strategies of English Department Students at 
Satya Wacana Christian University. A thesis of Bachelor Degree at Satya Wacana University, Salatiga: Published.

Sheorey, R., \& Mokhtari, K. (2001). Differences in the metacognitive awareness of reading strategies among native and nonnative readers. SYSTEM, 29(4), 1-19.

Shikano, M. (2013). A quantitative survey on metacognitive awareness of reading strategy use in English by Japanese university students. International Education Center Journal, 14, 11-24.

Solak, E., \& Altay, F. (2014). The Reading Strategies Used by Prospective English Teachers in Turkish ELT Context. International Online Journal of Education and Teaching, 1(2):78-89.

Tabatabaie, O. \& Assarim F. (2011). Investigating Strategic Processes of L2 Reading Comprehension among Collegiate Iranian ESP Learners across Three Academic Fields of Study. Canadian Research \& Development Center of Scieces and Cultures, 205-214.

Temur, T. \& Bahar, O. (2011). Metacognitive Awareness of Reading Strategies of Turkish Learners Who Learn English as a Foreign Language. European Journal of Educational Studies, 3(2), 421-427.

Yuksel, I. \& Yuksel, I. (2012). Metacognitive Awareness of Academic Reading Strategies. Procedia - Social and Behavioral Sciences, 31, 849-898.

Zarrabi, S. (2015). Exploring Metacognitive Online Reading Strategies of Non-Native English Speaking Translation Students. Doctoral Dissertation, University of San Francisco. 